\title{
Impact of Geriatric Nutritional Index in Contrast-Induced Nephropathy Developed in Patients with Non-ST Segment Elevation Myocardial Infarction who Underwent Percutaneous Coronary Intervention
}

\author{
Geriyatrik Beslenme İndeksinin Perkütan Koroner Girişim Uygulanmış \\ ST Segment Yükselmesiz Miyokard İnfarktüslü Hastalarda Gelişsen \\ Kontrast Kaynaklı Nefropati Üzerine Olan Etkisi
}

\section{Mehmet KUCUKOSMANOGLU $\odot$, Arafat YILDIRIM $\odot$, Fethi YAVUZ $\odot$, Mustafa DOGDUS $\odot$, Salih KILIC $\odot$}

Ethics Committee Approval: This study approved by the Adana Training and Research Hospital, Clinical Studies Ethic Committee, 22 May 2019, 2019/463.

Conflict of interest: The authors declare that they have no conflict of interest. Funding: None.

Informed Consent: Not Applicable.
Cite as: Kucukosmanoglu M, Yildirim A, Yavuz F, Dogdus M, Kilic S. Impact of geriatric nutritional index in contrast induced nephropathy in non-ST segment elevated myocardial infarction patients performed percutaneous coronary intervention. Medeniyet Med J. 2020;35:47-54

\begin{abstract}
Objective: Geriatric nutritional risk index (GNRI) is a useful tool to determine the nutritional status of patients. Any study has not evaluated the impact of GNRI in development of contrast- induced nephropathy (CIN) after percutaneous coronary intervention (PCI). We aimed to evaluate whether GNRI could predict CIN after PCI.

Method: A total of 1116 patients with non-ST elevation myocardial infarction (non-STEMI) that underwent PCI were enrolled to the present study. The GNRI was calculated using a previously reported formula: GNRI $=14.89 \times$ albumin $(\mathrm{g} / \mathrm{dL})+41.7 \times$ body weight $(\mathrm{kg}) /$ ideal body weight $(\mathrm{kg})$. CIN was defined as an increase in serum creatinine level of $\geq 0.5 \mathrm{mg} / \mathrm{dL}$ or $\geq 25 \%$ above baseline within 72 hours after the $P C I$ procedure. The patients were categorized into two groups as CIN (+) and CIN (-).

Results: The mean age of the CIN (+) group was significantly higher than the CIN (-) group $(64.8 \pm 10.67 \mathrm{vs}$. $60.5 \pm 10.61$ years; $p<0.001)$. The mean values of height, weight, and body mass index were significanlty lower in $C I N(+)$ group than CIN (-) group ( $p<0.001$, for all). The mean of GNRI was significantly lower in the $C I N(+)$ group than the CIN (-) group (101.4 \pm 8.7 vs. 112.1 \pm 12.9 ; $p<0.001)$. Serum albumin level was significantly lower in the CIN (+) group $(3.71 \pm 0.52 \mathrm{~g} / \mathrm{dL}$ vs. $3.94 \pm 0.53 \mathrm{~g} / \mathrm{dL} ; p<0.001)$. Left ventricular ejec-

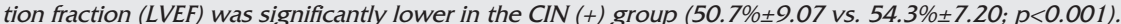
Conclusion: In this study, GNRI, serum albumin level, BMI, and LVEF were independent predictors of CIN. Moreover, GNRI was better than both serum albumin level and BMI in predicting development of CIN.
\end{abstract}

Keywords: Geriatric nutritional index, contrast induced nephropathy, percutaneous coronary intervention

öz

Amaç: Geriyatrik beslenme risk indeksi (GBi) hastaların beslenme durumunu belirlemek için kullanılan yararIı bir araçtır. GBi' nin perkütan koroner girişimler (PKG) sonrasında gelişen kontrast kaynaklı nefropati (KKN) gelișimi ile ilisskisini değerlendiren bir çalısma yoktur. Biz bu çalıșmamızda GBínin PKG sonrası gelișen KKN'nin öngördürücüsü olup olmadığııı değerlendirmeyi amaçladık.

Yöntem: Merkezimizde ST segment yüksekliği olmayan miyokard infarktüsü tanısı almış ve PKG uygulanmıș 1116 hasta calısmaya dahil edildi. GBi hastane kayıtlarındaki veriler kullanılarak 14.89 × serum albumin (g/ dL) + $41.7 \times$ güncel vücut ağırlığı $(\mathrm{kg}) /$ ideal vücut ağırlığı $(\mathrm{kg})$ formülü ile hesaplandı. KKN, PKG işleminden sonraki 72 saat içinde serum kreatinin seviyesinin $\geq 0,5 \mathrm{mg} / \mathrm{dL}$ veya başlangış düzeyinden $\geq \% 25$ oranında artması olarak tanımlandı. Hastalar KKN gelişenler (KKN(+)) ve KKN geliş̧meyenler (KKN(-)) olarak iki gruba ayrildilar.

Bulgular: $K K N(+)$ grubunun yaş ortalaması $K K N(-)$ grubundan anlamlı olarak yüksekti $(64.8 \pm 10.67$ ve $60.5 \pm 10.61 ; p<0.001)$. Ortalama boy, kilo ve vücut kitle indeksi (VKi) değerleri KKN (+) grubunda KKN (-) grubuna göre anlamlı olarak daha düşüktü (hepsi için $p<0.001)$. GBi ortalaması $K K N(+)$ grubunda $K K N(-)$ grubundan anlamlı olarak daha düşüktü (101.4 \pm 8.7 vs. 112.1 \pm 12.9 ; $p<0.001)$. KKN (+) grubunda serum albümin düzeyi anlamlı olarak daha düşüktü $(3.71 \pm 0.52 \mathrm{~g} / \mathrm{dL}$ ve $3.94 \pm 0.53 \mathrm{~g} / \mathrm{dL} ; p<0.001)$. Sol ventrikül ejeksiyon fraksiyonu (SVEF) KKN (+) grubunda anlamlı derece de düşüktü $(\% 50.7 \pm 9.07$ ve $\% 54.3 \pm 7.20$; $p<0.001$ ).

Sonuc: Bu çalıșmada, GBi, serum albumin seviyesi, VKi ve SVEF KKN'in bağımsız belirleyicileri olarak tespit edildi. DahasI, GBi KKN gelişimini öngördürmede hem serum albümin seviyesinden hem de VKi'den daha iyi bulundu.

Anahtar kelimeler: Geriyatrik beslenme indeksi, kontrast kaynaklı nefropati, perkütan koroner girișim

(c) Copyright Istanbul Medeniyet University Faculty of Medicine. This journal is published by Logos Medical Publishing. Licenced by Creative Commons Attribution-NonCommercial 4.0 International (CC BY-NC 4.0)
Received: 24 December 2019

Accepted: 14 February 2020

Online First: 28 February 2020

Corresponding Author: M. Kucukosmanoglu ORCID: 0000-0001-9186-3642 Saglik Bilimleri University, Adana City Training and Research Hospital, Department of Cardiology, Adana, Turkey

drmehmetkoo@gmail.com

A. Yildirim

ORCID: 0000-0002-2798-7488

F. Yavuz

ORCID: 0000-0003-1913-4212

S. Kilic

ORCID: 0000-0002-3579-3747

Saglik Bilimleri University,

Adana City Training and Research Hospital, Department of Cardiology,

Adana, Turkey

M. Dogdus

ORCID: 0000-0002-3895-1923

Usak University,

Training and Research Hospital,

Department of Cardiology, Usak, Turkey 


\section{INTRODUCTION}

Contrast-induced nephropathy (CIN) is a commonly observed undesirable condition in patients undergoing percutaneous coronary intervention (PCI). CIN is related with poorer outcomes for patients, including need for renal dialysis and higher mortality ${ }^{1-3}$. Previous studies reported that the prevalence of CIN after CAG or $\mathrm{PCI}$ procedures range from $2 \%-15 \%$ and can reach up to $50 \%$ in patients under high risk such as diabetes mellitus (DM) and pre-procedural renal failure ${ }^{4,5}$. CIN was previously defined as an increase in baseline serum creatinine level $(\mathrm{Cr}) 25 \%$ or $0.5 \mathrm{mg} /$ $\mathrm{dL}$ within 48-72 $\mathrm{h}$ after $\mathrm{PCl}^{1-3}$. Although, the physiological mechanisms of CIN are not certain, oxidative stress, inflammation, renal medullary hypoxia, and negative effects of contrast media are supposed to be the underlying physiological mechanisms ${ }^{6-9}$. The previous studies determined that age, DM, heart failure, anemia, chronic (preexisting) kidney disease, hypoalbuminemia, metabolic syndrome, overuse of high osmolar contrast medium, and peripheral vascular disease are predictors of $\mathrm{CIN}^{1-9}$. Also, relation between body mass index (BMI) and development of CIN were evaluated in different studies and the results are confounding ${ }^{1-4}$. The clinical impact of malnutrition has been shown in chronic kidney disease and cardiovascular diseases ${ }^{5-8}$. Geriatric nutritional risk index (GNRI) is a simple tool to identify the nutritional status of subjects. The clinical impact of GNRI has been demonstrated in many diseases912. GNRI is calculated using a simple formula that contains albumin and BMI.

According to past medical knowledge and consensus, the impact of GNRI in development of CIN after PCI in non-ST-segment elevation myocardial infarction (NSTEMI) patients has not been evaluated yet. The aim of present study is evaluation of whether GNRI could predict CIN after PCI in NSTEMI patients.

\section{MATERIAL and METHODS}

All patients diagnosed with non-STEMI who had undergone PCI in our center between January 1 , 2018 and December 31, 2018 were retrospectively enrolled in the present study. Patients that were followed-up with medical therapy, those with a history of heart failure, active malignancy, hematologic disorder, kidney transplantation or end-stage renal disease requiring dialysis, nephrotic syndrome, liver dysfunction, systemic immune system, or connective tissue disease or given contrast media within the last two weeks, were excluded from the study. Also, patients who had used the nephrotoxic drugs during periprocedural period, and had not measured their serum creatinine levels before and 72 hours after the procedure were excluded from the study. Patients with typical chest pain, objective signs of myocardial ischemia, and elevated biochemical markers of myocardial necrosis were diagnosed with NSTEMI ${ }^{13}$. All patients included in the study received same low-osmolar contrast material.

Hypertension was defined as systolic and diastolic blood pressures $\geq 140 / 90 \mathrm{mmHg}$ or use of any antihypertensive drug. Diabettes mellitus (DM) was defined as fasting blood glucose $\geq 126 \mathrm{mg}$ / $\mathrm{dL}$ or HbA1c $\geq 6.5$ or use of any antidiabetic drug. Dyslipidemia was determined as total cholesterol level $>200 \mathrm{mg} / \mathrm{dL}$, and/or undergoing treatment with statins and/or lipid-lowering agents. Current smoker was defined as the patient smoking at least 1 cigarette/day for at least one year.

The baseline characteristics of patients were recorded from patients' files, and routine laboratory parameters were retrieved from the hospital laboratory digital system. Transthoracic echocardiography was performed by experienced echocardiographers according to relevant guidelines ${ }^{14}$. GNRI values were calculated from the hospital admission database. The GNRI was calculated using a previously reported formula: GNRI $=14.89$ $\times$ albumin $(\mathrm{g} / \mathrm{dL})+41.7 \times$ body weight $(\mathrm{kg}) /$ ide- 
al body weight $(\mathrm{kg})$. The ideal body weight was calculated as follows: body height - 100 - [(body height -150)/4] for males, and body height - 100 [(body height - 150)/2.5] for females. The patients were classificated into CIN (+) and CIN (-) groups. The local ethics committee approved the protocol of the study.

\section{Statistical analyses}

Continuous variables with normal distribution were summarized as mean ( \pm standart deviation) and compared between groups with Student's ttest. Variables without normal distribution summarized as median and interquartile range and compared between groups with Mann-Whitney U-test. Categorical variables were summarized as numbers and percentages and compared using chi-square test. To demonstrate the sensitivity and specificity of GNRI, albumin, and BMI and their cut-off values for CIN development, the receiver operating characteristics (ROC) curve was used. The area under curve (AUC) comparison of GNRI, albumin, and BMI were performed using the Delong method ${ }^{15}$. To predict independent parameter for CIN development multivariate logistic regression analysis were performed.

Two programs were used for statistical analysis: Statistical Package for the Social Sciences (SPSS 20.0) (SPSS Inc., Chicago, Illinois, USA) and MedCalc 15 statistical software (Ostend, Belgium). Statistical significance was considered when $p$ value was $<0.05 \%$.

\section{RESULTS}

During the study period, 1116 patients (33.4\% female, mean age $60.61 \pm 10.73$ years) were included in the study. Of those, 190 (17.0\%) developed CIN. Baseline demographic and medical characteristics of groups are presented in Table 1. Compared to the CIN (-) group, the mean age of the CIN (+) group was statistically significantly higher $(64.8 \pm 10.7$ vs. $60.5 \pm 10.6 ; p<0.001)$. The mean values of height, body weight, and BMI were significanlty lower in CIN (+) group than

Table 1. Baseline demographic and clinical characteristics and echocardiographic parameters of patients.

\begin{tabular}{|c|c|c|c|c|}
\hline Parameters & $\begin{array}{l}\text { All Patients } \\
N=1116\end{array}$ & $\begin{array}{l}\text { CIN (+) } \\
\mathbf{N}=190\end{array}$ & $\begin{array}{l}\text { CIN (-) } \\
\mathbf{N}=926\end{array}$ & $\mathbf{P}$ \\
\hline Age, year & $60.61 \pm 10.73$ & $64.8 \pm 10.67$ & $60.5 \pm 10.6$ & $<0.001^{*}$ \\
\hline Weight, kg & $77.4 \pm 13.4$ & $66.6 \pm 5.2$ & $79.6 \pm 13.5$ & $<0.001$ * \\
\hline Height, m & $1.67 \pm 0.08$ & $1.65 \pm 0.08$ & $1.67 \pm 0.07$ & $<0.001^{*}$ \\
\hline $\mathrm{BMI}, \mathrm{kg} / \mathrm{m}^{2}$ & $27.3 \pm 4.6$ & $26.6 \pm 4.1$ & $28.43 \pm 4.59$ & $<0.001^{*}$ \\
\hline Female, \% (n) & $33.8(377)$ & $34.7(66)$ & $33.6(311)$ & 0.760 \\
\hline Obesity, \% (n) & $30.2(337)$ & $19.5(37)$ & $32.4(300)$ & $<0.001^{*}$ \\
\hline Diabetes mellitus, \% (n) & $38.1(425)$ & $44.7(85)$ & 36.7 (340) & $0.038^{*}$ \\
\hline Hypertension, \% (n) & $69.4(775)$ & $68.9(131)$ & $69.5(644)$ & 0.870 \\
\hline Hyperlipidemia, \% (n) & $39.0(435)$ & $36.3(69)$ & $39.5(366)$ & 0.409 \\
\hline Heart failure, $\%(n)$ & $15.4(171)$ & $17.4(33)$ & $14.9(138)$ & 0.397 \\
\hline Chronic obstructive pulmonary disease, \% (n) & $12.2(136)$ & $7.9(15)$ & $13.1(121)$ & 0.047 \\
\hline Smoker, \% (n) & $40.1(447)$ & $33.2(63)$ & $41.5(384)$ & $0.033^{*}$ \\
\hline Stroke, \% (n) & $3.4(38)$ & $4.2(8)$ & $3.2(30)$ & 0.505 \\
\hline GNRI & $110.3 \pm 12.9$ & $101.4 \pm 8.7$ & $112.1 \pm 12.9$ & $<0.001^{*}$ \\
\hline Contrast volume $(\mathrm{mL})$ & $182.6 \pm 58.6$ & $177 \pm 49.5$ & $183 \pm 60$ & 0.183 \\
\hline \multicolumn{5}{|l|}{ Echocardiography Parameters } \\
\hline LVESV, mL & $55.2 \pm 15.1$ & $60.5 \pm 18.42$ & $54.1 \pm 13.99$ & $<0.001^{*}$ \\
\hline LVEDV, mL & $118 \pm 19.5$ & $121.5 \pm 20.68$ & $118.0 \pm 19.29$ & $0.027^{*}$ \\
\hline LVEF, \% & $53.7 \pm 7.67$ & $50.7 \pm 9.07$ & $54.3 \pm 7.20$ & $<0.001$ * \\
\hline sPAP, mmHg & $22.7 \pm 5.65$ & $23.6 \pm 4.89$ & $22.6 \pm 5.79$ & 0.898 \\
\hline
\end{tabular}

BMI: body mass index, CIN: contrast induced nephropathy, GNRI: geriatric nutritional index, LVEDV: left ventricular end-diastolic volume, LVEF: left vetricular ejection fraction, LVESV: left vetricular end-systolic volume, sPAP: systolic pulmonary artery pressure. *Statistically significant 
Table 2. Comparision of blood parameters of patients.

\begin{tabular}{|c|c|c|c|c|}
\hline Parameters & $\begin{array}{l}\text { All Patients } \\
N=1116\end{array}$ & $\begin{array}{l}\text { CIN (+) } \\
\mathbf{N}=190\end{array}$ & $\begin{array}{l}\text { CIN (-) } \\
N=926\end{array}$ & $\mathbf{P}$ \\
\hline Total Protein, (g/dL) & $6.64 \pm 0.83$ & $6.59 \pm 0.62$ & $6.65 \pm 0.87$ & 0.356 \\
\hline Albumin, $(\mathrm{g} / \mathrm{dL})$ & $3.9 \pm 0.5$ & $3.71 \pm 0.52$ & $3.94 \pm 0.53$ & $<0.001$ * \\
\hline Pre-Procedural Creatinine, (mg/dL) & $0.87 \pm 0.34$ & $0.84 \pm 0.33$ & $0.88 \pm 0.34$ & 0.160 \\
\hline Post-Procedural Creatinine, $(\mathrm{mg} / \mathrm{dL})$ & $0.97 \pm 0.40$ & $1.24 \pm 0.58$ & $0.91 \pm 0.33$ & $<0.001^{*}$ \\
\hline Uric acid, (mg/dL) & $5.54 \pm 1.52$ & $5.91 \pm 2.04$ & $5.47 \pm 1.36$ & $0.005^{*}$ \\
\hline Total bilirubin, (mg/dL) & $0.55 \pm 0.31$ & $0.51 \pm 0.27$ & $0.56 \pm 0.32$ & $0.046^{*}$ \\
\hline WBC, $\left(10^{9} / \mathrm{L}\right)$ & $9100 \pm 2890$ & $9572 \pm 3347$ & $9016 \pm 2781$ & $0.033^{*}$ \\
\hline Haemoglobin, (g/dL) & $13.8 \pm 5.37$ & $13.0 \pm 2.20$ & $14.0 \pm 5.80$ & $0.022^{*}$ \\
\hline Haematocrit, $\%$ & $40.2 \pm 5.1$ & $38.7 \pm 5.9$ & $40.5 \pm 4.89$ & $<0.001 *$ \\
\hline Platelet, $\left(10^{9} / \mathrm{L}\right)$ & $244 \pm 73$ & $235 \pm 83$ & $246 \pm 71$ & 0.117 \\
\hline Lymphocyte, $\left(10^{\circ} / \mathrm{L}\right)$ & $2160 \pm 960$ & $2159 \pm 1036$ & $2162 \pm 951$ & 0.971 \\
\hline Neutrophil, $\left(10^{9} / \mathrm{L}\right)$ & $5930 \pm 2432$ & $6359 \pm 2934$ & $5841 \pm 2308$ & $0.023^{*}$ \\
\hline Monocyte, $\left(10^{9} / \mathrm{L}\right)$ & $1020 \pm 650$ & $1053 \pm 484$ & $1012 \pm 686$ & 0.333 \\
\hline Total cholesterol (mg/dL) & $186 \pm 43$ & $179 \pm 38$ & $188 \pm 44$ & $0.004^{*}$ \\
\hline LDL-C (mg/dL) & $121 \pm 34$ & $119 \pm 32$ & $122 \pm 35$ & 0.226 \\
\hline HDL-C (mg/dL) & $40 \pm 11$ & $38 \pm 10$ & $40 \pm 11$ & $0.011^{*}$ \\
\hline Triglyceride (mg/dL) & $163 \pm 99$ & $147 \pm 77$ & $166 \pm 103$ & $0.005^{*}$ \\
\hline Glucose, (mg/dL) & $148 \pm 75$ & $169 \pm 85$ & $144 \pm 72$ & $<0.001^{*}$ \\
\hline HbA1c, \% & $6.6 \pm 1.8$ & $6.77 \pm 1.62$ & $6.61 \pm 1.79$ & 0.262 \\
\hline Troponin I, (ng/L) & $66(18-456)$ & $166(30-1792)$ & $58(18-368)$ & $<0.001$ * \\
\hline BNP, (ng/L) & $246(98-1210)$ & $260(87-1600)$ & $274(94-1053)$ & 0.341 \\
\hline
\end{tabular}

BNP: brain natriuretic peptide, CIN: contrast induced nephropathy, HDL-C: high density lipoprotein cholesterol, LDL-C: low density lipoprotein cholesterol.

* Statistically significant

Table 3. Logistic regression analysis for predictors of contrast-induced nephropathy.

\begin{tabular}{|c|c|c|c|c|}
\hline \multirow{2}{*}{$\begin{array}{l}\text { Analysis } \\
\text { Variables }\end{array}$} & \multirow{2}{*}{\multicolumn{2}{|c|}{$\begin{array}{l}\text { Univariate } \\
\text { OR [95\% CI] }\end{array}$}} & \multicolumn{2}{|r|}{ Multivariate } \\
\hline & & & $\mathbf{P}$ & OR $[95 \% \mathrm{CI}]$ \\
\hline Age (per 1 year increase) & $<0.001 *$ & $1.036(1.020-1.052)$ & - & - \\
\hline Diabetes mellitus (yes vs. no) & $0.039^{*}$ & $1.395(1.018-1.913)$ & - & - \\
\hline Weight (per $1 \mathrm{~kg}$ decrease) & $<0.001 *$ & $0.867(0.845-0.890)$ & - & - \\
\hline BMI (per $1 \mathrm{~kg} / \mathrm{m}^{2}$ decrease) & $<0.001^{*}$ & $0.905(0.870-0.943)$ & $0.004^{*}$ & $0.942(0.905-0.981)$ \\
\hline Albumin (per $1 \mathrm{~g} / \mathrm{dL}$ decrease) & $<0.001^{*}$ & $0.468(0.355-0.619)$ & $0.019^{*}$ & $0.979(0.962-0.996)$ \\
\hline GNRI (per 1 point decrease) & $<0.001^{*}$ & $0.871(0.848-0.895)$ & $<0.001^{*}$ & $0.762(0.725-0.801$ \\
\hline LVEF (per $1 \%$ decrease) & $<0.001^{*}$ & $0.949(0.932-0.966)$ & $0.009^{*}$ & $0.971(0.951-0.993)$ \\
\hline Uric acid (per $1 \mathrm{mg} / \mathrm{dL}$ increase) & $<0.001^{*}$ & $1.177(1.080-1.310)$ & - & - \\
\hline Hemoglobin (per $1 \mathrm{~g} / \mathrm{dL}$ decrease) & $<0.001^{*}$ & $0.847(0.782-0.918)$ & - & - \\
\hline HDL-C (per $1 \mathrm{mg} / \mathrm{dL}$ decrease) & $0.011^{*}$ & $0.981(0.966-0.996)$ & - & - \\
\hline Triglyceride (per $1 \mathrm{mg} / \mathrm{dL}$ decrease) & $0.020^{*}$ & $0.998(0.996-1.000)$ & - & - \\
\hline Troponin (per $1 \mathrm{ng} / \mathrm{dL}$ increase) & $<0.001^{*}$ & $1.001(1.000-1.001)$ & - & - \\
\hline
\end{tabular}

BMI: body mass index, HDL-C: high denstiy, GNRI: geriatric nutritional index, LVEF: left vetricular ejection fraction *Statistically significant

CIN (-) group ( $p<0.001$, for all). Compared to the CIN (-) group, the rates of smoking and chronic obstructive pulmonary disease were significantly lower in the CIN (+) group ( $p<0.05$, for both). Left ventricular ejection fraction (LVEF) was significantly higher in the CIN (-) group than CIN (+) group $(54.3 \% \pm 7.2 \%$ vs. $50.7 \% \pm 9.1 \%$; $p<0.001)$.
Laboratory parameters of groups are summarized in Table 2. Serum albumin level was significantly lower in the CIN $(+)$ group $(3.71 \pm 0.52 \mathrm{~g} / \mathrm{dL}$ vs. $3.94 \pm 0.53 \mathrm{~g} / \mathrm{dL} ; \mathrm{p}<0.001$ ). Pre-procedural serum creatinine levels were similar between groups (CIN (+) $0.84 \pm 0.33 \mathrm{mg} / \mathrm{dL}$ vs. CIN (-) $0.88 \pm 0.34$ $\mathrm{mg} / \mathrm{dL} ; \mathrm{p}<0.160$ ), as expectedly post-procedural 
creatinine levels were statistically higher in the CIN (+) group $(1.24 \pm 0.58 \mathrm{mg} / \mathrm{dL}$ vs. $0.91 \pm 0.33$ $\mathrm{mg} / \mathrm{dL} ; \mathrm{p}<0.001)$. Also, mean serum uric acid level, and white blood cell (WBC) count were significantly higher and hemoglobin level was lower in the CIN (+) group than the CIN (-) group (Table 2 ). The mean GNRI was significantly lower in the CIN (+) group than the CIN (-) group $(101.4 \pm 8.7$ vs. 112.1 $\pm 12.9 ; \mathrm{p}<0.001$ ) (Table 1 ).

To predict CIN development, the cut-off value of albumin $\leq 3.8 \mathrm{~g} / \mathrm{dL}$ has a $60.0 \%$ sensitivity and 65.66\% specificity (AUC: 0.637; 95\% confidence interval [Cl] 0.608-0.665; $\mathrm{p}<0.001$ ) and $\mathrm{BMI} \leq 27$ $\mathrm{kg} / \mathrm{m}^{2}$ has a $66.32 \%$ sensitivity and $51.51 \%$ specificity (AUC: 0.615 ; 95\% Cl 0.586-0.644; $\mathrm{p}<0.001$ ), and GNRI $\leq 110.7$ has a $85.8 \%$ sensitivity and $55.2 \%$ specificity (AUC: $0.757 ; 95 \%$ Cl 0.731 $0.782 ; \mathrm{p}<0.001$ ) in the ROC curve analyses (Figure $1)$. In the pairwise comparison of ROC analyses, GNRI was found to be a statistically significant better than albumin and BMI in predicting development of CIN (for both; $\mathrm{p}<0.001$ ) (Figure 1).

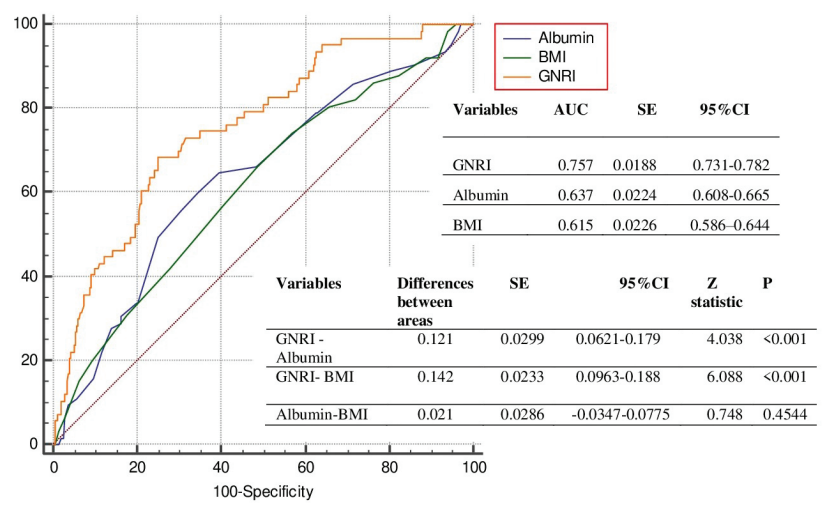

Figure 1. Comparison of Receiver operating characteristic (ROC) curves for CIN development.

AUC: area under the curve, BMI: body mass index, CI: confidence interval, GNRI: geriatric nutritional risk index, SE: standart error

To define the predictors of $\mathrm{CIN}$, univariate and multivariate logistic regression analyses were performed and results are summarized in Table 4. The univariate analysis demonstrated that history of DM, age, BMI, weight, LVEF, GNRI, and levels of troponin, uric acid, HDL-C, triglyceride, hemoglobin and albumin were predictors of CIN development. The multivariate analysis that examined age, BMI, weight, DM, LVEF, GNRI, and troponin, uric acid, HDL-C, triglyceride, hemoglobin and albumin levels demostrated that albumin (per 1 - g/dL decrease) (OR: 0.979; 95\% CI 0.9620.996; $\mathrm{p}=0.019$ ), BMI (per $1 \mathrm{~kg} / \mathrm{m}^{2}$ decrease) (OR: 0.942; 95\% CI: 0.905-0.981; $\mathrm{p}=0.004$ ), GNRI (per 1 point decrease) (OR: 0.762; 95\% Cl 0.725$0.801 ; p<0.001$ ), and LVEF (per 1\% decrease) (OR: 0.971; 95\% Cl 0.951-0.993; $p=0.009$ ) were the independent predictors of CIN development.

\section{DISCUSSION}

In our study, we showed that low values of GNRI, serum albumin, BMI, and LVEF were independent predictors of CIN. Moreover, GNRI was better than both serum albumin and $\mathrm{BMI}$ in predicting development of CIN after PCI.

CIN is a frequent cause of acute kidney disease in hospitalized patients. Published studies have reported an increase rate of CIN in patients diagnosed with acute coronary syndrome and had undergone $\mathrm{PCI}$. The prevalance of $\mathrm{CIN}$ in patients diagnosed with myocardial infarction and underwent PCI was found to be between 12 and 26\% ${ }^{16-}$ 18. Since there is no sole marker for CIN, many markers have been reported to be related with CIN development ${ }^{16-19}$. Previous medical history of diabetes mellitus (DM) or chronic kidney diseases have been shown to be significant risk factors of CIN development after $\mathrm{PCI}^{16-19}$. Also, the contrast agent volume is an important risk factor for CIN development. Moreover, many other risk factors that are related to CIN development have been reported in different studies that performed $\mathrm{PCl}$ including advanced age, previous history of heart failure, hypoalbuminemia, anemia, C-reactive protein, low BMI, nephrotoxic drugs use, hemodynamic instability, white blood cell count and use of intra-aortic ballon pump ${ }^{16-18,20-22}$. The pathophysiology of CIN is not clear. The inflammation, oxidative stess, renal medullar hypoxia, 
negative effects of contrast agents, impaired balance of vasodilation and vasoconstriction in renal medulla have been considered to be possible risk factors for the developmet of CIN. The association between hypoalbuminemia and cardiovascular morbidity/mortality has been shown in different studies. Moreover, studies have demonstrated that low serum albumin level is related to mortality in patients diagnosed with acute coronary syndrome ${ }^{17,23-25}$. However, the relationship between serum albumin and CIN is not clear, and several possible mechanisms may be involved. Antioxidative effects of albumin are important for the development of CIN. Because albumin is an important free oxygen radical capture from plasma and oxidative stress is a possible factor to the development of $\mathrm{CIN}$, the low level of albumin is an significant predictor of CIN development ${ }^{26,27}$. Another possible relationship between albumin and CIN may be explained by inceased inflammation status in CIN patients ${ }^{28,29}$. Due to an inverse relation between inflamation and albumin, low albumin levels in CIN patients might be explained by increased inflamation status. The relation between BMI and CIN development has been evaluated in different studies and the results are confounding ${ }^{1-4}$. Some studies have shown that low BMI, while others have established that a high BMI is a risk factor. Recently, Kuno et al. ${ }^{2}$ showed that the relationship between BMI and $\mathrm{CIN}$ is a reverse J-curve relationship and the incidence of CIN is high both in patients with BMIs $<20 \mathrm{~kg} / \mathrm{m}^{2}$ and $>30 \mathrm{~kg} / \mathrm{m}^{2}$ than those with BMIs between $20-30 \mathrm{~kg} / \mathrm{m}^{2}$. In the present study, we have shown that mean $\mathrm{BMI}$ of the $\mathrm{CIN}(+)$ group is lower than the CIN (-) group and BMI is an independent predictor of CIN development. GNRI is a simple index and well-established nutritional screening tool for elderly patients that has been evaluated in various cardiovascular diseases ${ }^{9-12,30}$. Malnutrition is common in patients suffered from a cardiovascular disease especially in heart failure patients ${ }^{10,30}$. The valid formula for the GNRI include serum albumin levels and weights of patients. Also, the formula included ideal weight of patients which is calculated from body height. In this present study, we showed that the GNRI is an independent predictor of CIN development. Moreover, it is significantly better than both serum albumin levels and BMI in predicting CIN development. The possible assocation between $\mathrm{CIN}$ development and malnutrition is not certain. The most possible symptom is inflammation. As emphasized above, inflammation is related to CIN development and malnutrition is closely associated with systemic inflammation. Consequently, patients with malnutrition are likely to experience CIN. Moreover, similar to BMI, GNRI is affected by both body weight and height. However, in the formula of GNRI the ideal body weight is also calculated which might explain the difference between BMI and GNRI. Many previous studies reported that CIN development is frequently seen in advanced age patients ${ }^{31-33}$. The possible mechanisms underlying CIN development in the elderly age is not clear but probably is associated with change in renal function with aging. In the present study, we found in the multivariate analysis, that age is not an independent predictor of CIN development. This might explain the reason why the mean age of study population was $60.61 \pm 10.73$ years. The contrast volume is a modifiable risk factor for development of CIN and previous studies established the association between contrast volume and the risk of CIN development ${ }^{33-35}$. In their study, Nikolsky et al. ${ }^{36}$ showed that increase of every $100 \mathrm{ml}$ in the amount of contrast material resulted in a $30 \%$ increase in the odds ratio of $\mathrm{CIN}$ development. In the present study, the mean volume of contrast material was $182.6 \pm 58.6 \mathrm{~mL}$ which was comparable between groups. Anemia might be associated with CIN development. A different study published by Nikolsky et al. showed that decreased level of pre-procedural hematocrit is related to CIN development ${ }^{37}$.

In the present study, the mean hematocrit and hemoglobin levels were found to be lower in the CIN (+) group. Although hemoglobin was a predictor of CIN development in the univariate 
analysis, it lost its significance in the multivariate analysis. Heart failure has been reported to be a risk factor for CIN development in patients pwho underwent $\mathrm{PCl}^{38}$. Similarly, in this study the mean level of LVEF was signifincantly lower in the CIN group. Moreover, LVEF was an independent predictor of CIN development.

\section{CONCLUSIONS}

In this study, we have determined that the prevelance of CIN development is significantly higher in patients diagnosed with non-STEMI and underwent PCI. In addition, GNRI is an independent predictor of CIN development and is better than BMI and serum albumin level in patients diagnosed with non-STEMI who underwent PCI.

\section{Study limitations}

The main limitation of our study is its retrospective single- centered design. All patients diagnosed as post-PCI nephropathy which might be related to an extraneous causes as pre-renal disorders or cholestrol emboli. However, due to the nature of the study design it is not possible to diagnose these infrequently seen etiologies. Another limitation is that although we included all consecutive patients, some patients might be discharged after $\mathrm{PCI}$ without controlling their creatinine levels. But due to the sufficient number of patients in two groups, we believe that our results accurately reflect the patient population as a sample group. Another important limitation of study was that we included only patients diagnosed with nonSTEMI.

\section{REFERENCES}

1. Rihal CS, Textor SC, Grill DE, et al. Incidence and prognostic importance of acute renal failure after percutaneous coronary intervention. Circulation. 2002;105:225964. [CrossRef]

2. Kuno T, Numasawa $Y$, Sawano $M$, et al. Effects of body habitus on contrast-induced acute kidney injury after percutaneous coronary intervention. PLoS One. 2018;13:e0203352. [CrossRef]

3. Zhang MM, Lv QZ, Li XY. Drug effects and clinical investigations for contrast-induced nephropathy after coro- nary angiography or percutaneous coronary intervention in patients with diabetes. Am J Ther. 2017;24:e423-e30. [CrossRef]

4. Mehran R, Nikolsky E. Contrast-induced nephropathy: definition, epidemiology, and patients at risk. Kidney International. 2006;69:S11-S15. [CrossRef]

5. Bonilla-Palomas JL, Gámez-López AL, Anguita-Sánchez $\mathrm{MP}$, et al. Impact of malnutrition on long-term mortality in hospitalized patients with heart failure. Rev Esp Cardiol. 2011;64:752-8. [CrossRef]

6. Cheng YL, Sung SH, Cheng HM, et al. Prognostic Nutritional Index and the risk of mortality in patients with acute heart failure. J Am Heart Assoc. 2017;6:e004876. [CrossRef]

7. Kunimura A, Ishii $H$, Uetani $T$, et al. Impact of Geriatric Nutritional Risk Index on cardiovascular outcomes in patients with stable coronary artery disease. J Cardiol. 2017;69:383-8. [CrossRef]

8. Nochioka K, Sakata Y, Takahashi J, et al. Prognostic impact of nutritional status in asymptomatic patients with cardiac diseases. Circulation Journal. 2013;77:2318-26. [CrossRef]

9. Yokoyama M, Watanabe T, Otaki Y, et al. Impact of objective malnutrition status on the clinical outcomes in patients with peripheral artery disease following endovascular therapy. Circ J. 2018;82:847-56. [CrossRef]

10. Narumi T, Arimoto T, Funayama A. The prognostic importance of objective nutritional indexes in patients with chronic heart failure. J Cardiol. 2013;62:307-13. [CrossRef]

11. Mas-Peiro S, Papadopoulos N, Walther T, Zeiher AM, Fichtlscherer $S$, Vasa-Nicotera $M$, Nutritional risk index is a better predictor of early mortality than conventional nutritional markers after trans-catheter aortic valve replacement: A prospective cohort study. Cardiol J. 2019;10.5603/CJ.a2019.0038. [CrossRef]

12. La Rovere MT, Maestri R, Olmetti F, et al. Additional predictive value of nutritional status in the prognostic assessment of heart failure patients. Nutr Metab Cardiovasc Dis. 2017;27:274-80. [CrossRef]

13. Hamm CW, Bassand JP, Agewall S, et al. ESC Guidelines for the management of acute coronary syndromes in patients presenting without persistent ST-segment elevation: The Task Force for the management of acute coronary syndromes (ACS) in patients presenting without persistent ST-segment elevation of the European Society of Cardiology (ESC). Eur Heart J. 2011;32:2999-3054. [CrossRef]

14. Zamorano JL, Badano LP, Bruce C, et al. EAE/ASE recommendations for the use of echocardiography in new transcatheter interventions for valvular heart disease. Eur Heart J. 2011;32:2189-214. [CrossRef]

15. DeLong ER, DeLong DM, Clarke-Pearson DL. Comparing the areas under two or more correlated receiver operating characteristic curves: a nonparametric approach. Biometrics. 1988;44:837-45. [CrossRef]

16. Taliercio CP, Vlietstra RE, Fisher LD, et al. Risks for renal dysfunction with cardiac angiography. Ann Intern Med. 1986;104:501-4. [CrossRef]

17. Mehran R, Aymong ED, Nikolsky E, et al. A simple risk score for prediction of contrast-induced nephropathy after percutaneous coronary intervention: development and initial validation. J Am Coll Cardiol. 2004;44:1393-9. [CrossRef]

18. Tsai TT, Patel UD, Chang TI, et al. Contemporary inci- 
dence, predictors, and outcomes of acute kidney injury in patients undergoing percutaneous coronary interventions: insights from the NCDR Cath-PCI registry. JACC Cardiovasc Interv. 2014;7:1-9. [CrossRef]

19. Manske CL, Sprafka JM, Strony JT, Wang Y. Contrast nephropathy in azotemic diabetic patients undergoing coronary angiography. Am J Med. 1990;89:615-20. [CrossRef]

20. Ali-Hasan-Al-Saegh S, Mirhosseini SJ, Ghodratipour Z, et al. Strategies preventing contrast-induced nephropathy after coronary angiography: a comprehensive meta-analysis and systematic review of 125 randomized controlled trials. Angiology. 2017;68:389-413. [CrossRef]

21. Vlietstra RE, Nunn CM, Narvarte J, Browne KF. Contrast nephropathy after coronary angioplasty in chronic renal insufficiency. Am Heart J. 1996;132:1049-50. [CrossRef]

22. McCullough PA, Wolyn R, Rocher LL, Levin RN, O'Neill WW. Acute renal failure after coronary intervention: incidence, risk factors, and relationship to mortality. Am J Med. 1997;103:368-75. [CrossRef]

23. Oduncu V, Erkol A, Karabay CY, et al. The prognostic value of serum albumin levels on admission in patients with acute ST-segment elevation myocardial infarction undergoing a primary percutaneous coronary intervention. Coron Artery Dis. 2013;24:88-94. [CrossRef]

24. Hartopo AB, Gharini PP, Setianto BY. Low serum albumin levels and in-hospital adverse outcomes in acute coronary syndrome. Int Heart J. 2010;51:221-6. [CrossRef]

25. Sgura FA, Bertelli L, Monopoli D, et al. Mehran contrastinduced nephropathy risk score predicts short-and longterm clinical outcomes in patients with ST-elevation-myocardial infarction. Circ Cardiovasc Interv. 2010;3:491-8. [CrossRef]

26. Roche M, Rondeau P, Singh NR, Tarnus E, Bourdon E. The antioxidant properties of serum albumin. FEBS Lett. 2008;582:1783-7. [CrossRef]

27. Bourdon E, Blache D. The importance of proteins in defense against oxidation. Antioxid Redox Signal. 2001;3:293-311. [CrossRef]

28. Don BR, Kaysen G. Serum albumin: relationship to inflammation and nutrition. Semin Dial. 2004;17:432-7. [CrossRef]
29. Liu Y, Tan N, Zhou YL, et al. High-sensitivity C-reactive protein predicts contrast-induced nephropathy after primary percutaneous coronary intervention. J Nephrol. 2012;25:332-40. [CrossRef]

30. Lin H, Zhang H, Lin Z, et al. Review of nutritional screening and assessment tools and clinical outcomes in heart failure. Heart Fail Rev. 2016;21:549-65. [CrossRef]

31. Parfrey PS, Griffiths SM, Barrett BJ, et al. Contrast materialinduced renal failure in patients with diabetes mellitus, renal insufficiency, or both. N Engl J Med. 1989;320:143-9. [CrossRef]

32. Gussenhoven MJ, Ravensbergen J, Van Bockel JH, Feuth JD, Aarts JC. Renal dysfunction after angiography; a risk factor analysis in patients with peripheral vascular disease. J Cardiovasc Surg (Torino). 1991;32:81-6.

33. Kini AS, Mitre CA, Kim M, et al. A protocol for prevention of radiographic contrast nephropathy during percutaneous coronary intervention: effect of selective dopamine receptor agonist fenoldopam. Catheter Cardiovasc Interv. 2002;55:169-73. [CrossRef]

34. Albert SG, Shapiro MJ, Brown WW, et al. Analysis of radiocontrast-induced nephropathy by dual-labeled radionuclide clearance. Invest Radiol. 1994;29:618-23. [CrossRef]

35. Diaz-Sandoval LJ, Kosowsky BD, Losordo DW. Acetylcysteine to prevent angiography-related renal tissue injury (the APART trial). Am J Cardiol. 2002;89:356-8. [CrossRef]

36. Nikolsky E, Mehran R, Turcot D, et al. Impact of chronic kidney disease on prognosis of patients with diabetes mellitus treated with percutaneous coronary intervention. Am J Cardiol. 2004;94:300-5. [CrossRef]

37. Nikolsky E, Mehran R, Lasic Z, et al. Low hematocrit predicts contrast-induced nephropathy after percutaneous coronary interventions. Kidney Int. 2005;67:706-13. [CrossRef]

38. Sedhai YR, Golamari R, Timalsina S, et al. ContrastInduced Nephropathy After Cardiac Catheterization: Culprits, Consequences and Predictors. Am J Med Sci. 2017;354:462-6. [CrossRef] 